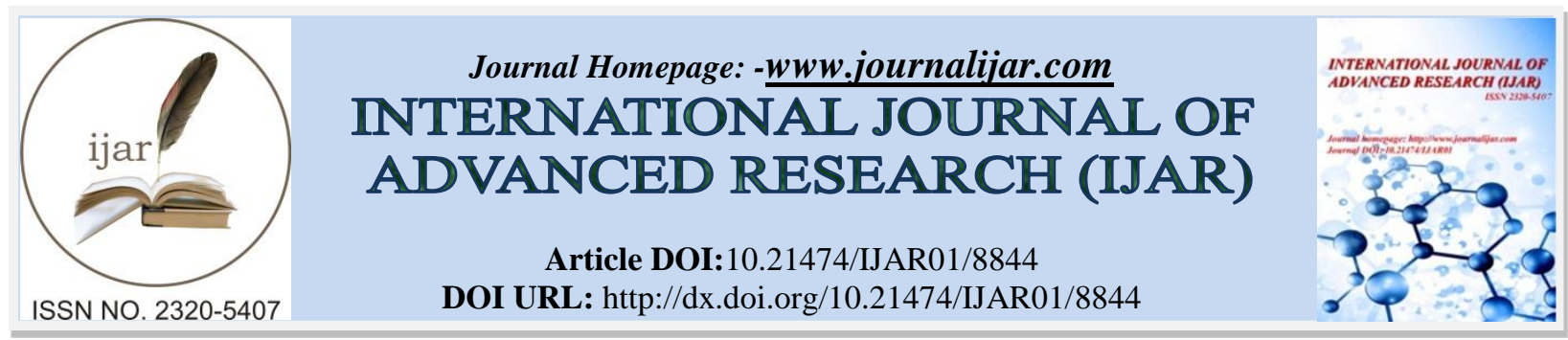

RESEARCH ARTICLE

\title{
INFLUENCE OF CLASSROOM MANAGEMENT ON THE INSTRUCTIONAL PROCESS; IMPLICATION FOR INNOVATION IN EDUCATION.
}

Nemine Ebi-Bulami Bridget (PhD) ${ }^{1}$, Torunariya Young Denson $(\mathbf{P h D})^{2}$ and Sele Anderson P. (PhD) ${ }^{1}$.

1. Faculty of Education, Department of Social Science Education Niger Delta University, Amassoma Wilberforce Island, Bayelsa State.

2. Faculty of Education, Department of Art Education Niger Delta University, Amassoma Wilberforce Island, Bayelsa State.

\section{Manuscript Info}

..........................

Manuscript History

Received: 07 February 2019

Final Accepted: 09 March 2019

Published: April 2019

Key words:-

Classroom, Management, Instructional

Process, Innovation.

\section{Abstract}

This paper examined influence of classroom management on instructional process and its implications in post primary education in Ekeremor Local Government Area of Bayelsa State. A sample of 100 teachers was drawn from a population of 261 teachers in five selected government owned post primary schools. Three research questions based on classroom management and effective instructional process (CMEIPQ) was the main instrument adopted. The percentage and mean are the statistical tools employed to analyze data collected from the respondents. Mean score above the criterion mean score of 2.50 were accepted while Mean score below the criterion mean score 2.50 were rejected. It was discovered that classroom management has great implication for effective delivery in the instructional process having a grand mean total of. Effective classroom management was also discovered to provide a calm environment for effective teaching and instructional process in post primary schools, while ineffective poor classroom management affects the instructional process negatively and this was traced to some certain factors such as, poor seating and setting arrangement, teachers inability to handle discipline any problems faced in the classroom, teachers been non-professionally trained, lack of teachers preparation, also lack of student concentration were seen to be another factor among many others. In light of this, ICT complaint strategies were recommended so as to enable learners from the comfort of their homes in some cases so as to eliminate issues such as poor seating and setting arrangement which are avoidable in this digital age.

Copy Right, IJAR, 2019,. All rights reserved.

\section{Introduction:-}

The instructional process is the pivot for formal education in any setting. Managing student behavior has always been a primary concern of teachers for student misbehaviors have interfered with positive learning environments. From the beginning of teaching experience, teachers commonly express their concern about controlling the students and creating a disciplined environment in order to create a proper atmosphere for learning, and classroom management is commonly mentioned as the most intricate aspect of teaching. 
First the classroom is an operational venue in schools which holds students together and offers them the opportunity of achieving the purpose of education. It is a room in a school where a group of students or children are taught the lesson. Thus, the classroom should be well managed and maintained to bring about healthy learning environment, relatively free from behavioral problems which goal should be to maintain a positive productive learning environment and quality performance. (Hill and Hill, 1990)

The quality of the physical environments, according to Edwards (1993), affects the performance of teachers as well as students.

There should be clarity about what classroom management is, so that its effect on learning environment could be understood. Since classroom management is a multifaceted concept, it is defined differently by various writers. Conceptions in classroom management are influenced by changes in research perspectives at various points since the late 1960s (Harris and Evertson, 1999 in Douyibo, 2016). Since that time the meaning of the term classroom management has changed from describing discipline practices and behavioural interventions to serving as a more holistic view of teachers' actions in orchestrating supportive learning environments and building community. In most general terms classroom management refers to the action and strategies teachers utilize to maintain order (Doyle, 1986 in Douyibo, 2016).

Classroom management is also seen as the teacher's ability to co-operatively manage time, space, resources, students' roles and behaviors to provide a climate that encourages learning (Alberto and Troutman 1986).

Duke (1979) viewed classroom management as the provisions and procedure necessary to establish and maintain an environment in which instructions and learning can occur. Classroom management involves a positive classroom environment, appropriate standards of behaviors for students, effective management of daily routines and instructions and engaging the students in classroom activities throughout the lessons to ensure quality secondary education (David, 1996).

The emphasis on classroom management therefore is dependent on components such as, an engaging curriculum, the teacher as a role model, students as responsible citizens, classroom management skills, robust instruction and working with resistant, conflict and stress. If any of this component is neglected the whole process is compromised, leading to poor quality in education.

Classroom management is the process of enhancing the learning environment, physical interaction between teachers and students, student to students, parents and others, stimulating and motivating children to learn, to learning objectives, control and supervision throughout the school to facilitate and encourage co-operation in teaching and learning activities in the classroom smoothly, will as a result, improve the quality of students performance, in (Wisetrainthng, Siriuthi and Weangs a moob, 2012).

Classroom management, therefore, could be seen as an integral part of effective teaching which defers behavior problems through good planning, organizing and managing of classroom activities, good presentation of instructional materials and good teacher-student interaction, leading to increasing students' involvement and cooperation in learning to ensure quality secondary education. Classroom management is an art and a science with many identifiable characteristics that results in smooth periods of learning, flexible enough to recognize what is needed and has the ability to keep control of the situations that arise.

\section{Relationship between Classroom Management and the Instructional Process}

Effective classroom management begins with mutual respect and inter personal relationships and is vital to improve student achievement and teacher self-efficacy. It requires commitment to student and their learning, because a positive rapport with students is the foundation upon which classroom culture is built. Effective classroom management is an essential ingredient that promotes and enhances good instructional environment which eventually leads to quality secondary education.

The teacher and other members of staff must cooperate to manage the classroom, students, non-human resources and the environment. Effective classrooms management revolves around teachers; attitudes, skills, desires, setting of expectations and positive actions. To improve classroom behavior and students social skills, the teacher must conceptualize the process of teaching and understand classroom management principles for making professional 
decisions on classroom management. A well-managed classroom should strike a balance between consistent disciplines and praise (Venkat, 2010).

The relationship between classroom management and student learning makes the issue of classroom management of critical importance. Classrooms management was often viewed as the same with discipline in the past. Historically, management research focused on teachers "reaction to students" misbehavior, However, many researchers claim that they are not same, classroom management is much more that of controlling the students and preventing misbehavior. (Brophy and Sood, 2003), according to them, classroom management is different from a discipline plan. It includes the teachers' beliefs and values, as they relate to discipline, but also how they intertwine with various underlying aspects of the class structure. They suggested that there are mainly three aspects-the physical environment of the classroom, the amount of teacher preparation and ways in which the lesson is presented, which influence classroom management is the organization of all these aspects in a classroom.

Marzano and Marzono (2003) also stated that classroom management is a key to high student achievement. In their research, they found out that teachers' action in their classroom have twice the impact on students achievement as do school policies regarding curriculum, assessment, staff collegiality and community involvement.

An effective classroom manager provides effective instruction, so management is an integral part of the learning process.

\section{Theoretical Approaches to Classroom Management}

There are three theoretical approaches to the management problem namely the non-interventionist, the interventionist and the integrationist (Levin and Nolan, 1991).

The Non-interventionist approach, based on humanistic and psychoanalytic theories of development suggests that the child develops from an inner unfolding of potential. The teacher's role is to facilitate this process by promoting strong, trusting relationship with children and helping them develop their problem-solving abilities. The major goal of the non-interactionist approach is to enhance the personal growth and freedom of the individual, in the teaching learning process in secondary schools.

The interactionist approach, based on behaviourist approach, suggests that children develop as a result of external environmental conditions such as reinforcement and punishment. The teachers' role in the classroom is to enforce rules and procedures, communicate these clearly to students and implement appropriate rewards and punishment for compliance or non-compliance respectively. The major goal of the interventionist approach is to maintain an orderly and productive classroom that promotes quality secondary education.

The interactionist approach, based on social, gestalt and developmental psychological theories view child's development as the interaction of inner and outer forces. The teacher's role is to understand student's behavior and to help students understand their own behavior and its consequences. The major emphasis of this approach is how the established rules and regulations can be obeyed by the students concerned.

\section{Empirical Researchers on Classroom Management}

Using ABCD (Attitude, Beliefs about classroom control) inventory, Martin and his colleagues investigated the relationship between teachers' perception of classroom management and other factors such as gender, age, classroom management training, size, graduate studies, teacher characteristics and school setting. While exploring the classroom management styles of teachers' in these studies the researchers sometimes have come across with significant relationship between the classroom management approach and other factors, sometimes not. These studies have particular importance for his study as they show the important variables affecting the classroom management style.

In a study on the impact of teachers' experience levels on classroom management practices, Martin and Baldwin (1994) investigated the classroom management approaches of 238 teachers by using ICMS (Inventory of classroom management style). As a result, they found that novice teachers were significantly more interventionist than were experienced teachers. In another study examining gender differences, Marton and Yin (1997) discovered that females were significantly less interventionist that were males regarding instructional management and regarding student management. 
However, in another study Martin, Yin and Baldwin (1997) found no gender differences related to any of the classroom management approaches. In 1998 Martin, Yin and Baldwin investigated the relationship between classroom management attitudes and classroom management training, class size and graduate study. Data were collected from 281 certified teachers, who were primarily working in urban schools and were females.

Results showed significant difference of the ABCC instructional classroom management subscale of the ABCC regarding classroom management training as well as significant positive correlations between average class enrollment and teachers scores on the people management and behavior management subscales ABCC. A one way analysis of variance did not yield significant difference between the teachers who had enrolled in graduate courses in 6 months and those who did not.

Although class size has likely a direct impact on the nature of instruction as well as teacher-student interaction, the results of this study showed no significant difference in teacher's classroom management styles regarding class size. Gibbs (2004) also investigated if there was a difference between the attitudes and beliefs of traditionally and alternatively certified teachers regarding classroom management. By employing the ABCC invention on 114 high school teachers, t-test was used to compare the result of two groups on three classroom management dimensions, people, behavior instructional dimensions. Results revealed that in all three dimensions, there was no statistical significant difference between the attitudes and beliefs of alternatively certified and traditionally certified teachers. The overall findings held similar attitude towards classroom management.

Garret (2005) also studied student centered and teacher-centered classroom management strategies by employing qualitative research methods. The purpose of her study was to explore the classroom management strategies used by three teachers who apply student centered approach to their instruction and to examine the relationship between their managerial and instructional approaches. As a result, she found out that the way teacher thinks about the relationship between their instructional and managerial approaches was influenced by what they see as the overall goal of classroom management while two of them have a classroom management strategy consistent with their way of instruction, one does not.

\section{Statement of the Problem}

Problems are natural phenomena. The nature and causes of student problems in the instructional process are what this study intends to highlight. Students behave in different ways which in most cases affect classroom instruction. Why secondary school students of this age are proving very difficult to control is a matter of concern to most educational researchers.

Another area worth mentioning is how to determine the causes of these entry behaviors of students. Such behaviors do not give the student and teacher the desired learning condition for a sound transfer or facilitation of knowledge which is the primary aim of education. The other side of the problem is to determine to what extent the students' problem in the instructional process affect their academic performance.

Therefore, the main problem of the study is to find out classroom management problems teachers' face, how they affect the instructional process and how these problems can be managed.

\section{Purpose of the Study}

The purpose of the study, is to examine classroom management and implications. It has in the instructional process in secondary schools in Ekeremor Local Government Area of Bayelsa State. The study guided by the following objectives:

1. To identify the causes of poor classroom management in Ekeremor Local Government Area (EKELGA) of Bayelsa State.

2. To identify the effect of poor classroom management on the instructional process

3. To examine the implications of effective classroom management on effective delivery in the instructional process.

4. To identify ways to enhance effective classroom management

\section{Research Questions}

To achieve the above objectives, the following research questions are posed.

1. What are the causes of poor classroom management 
2. What are the effect of poor classroom management for effective delivery in the instructional process?

3. What are the implications of effective classroom management for an effective instructional process?

\section{Significance of the Study}

This study is directed at the classroom management and implication for effective delivery in the instructional process with the view of providing considerable information and knowledge in the study area.

It is also hoped that this study would contribute positively to existing body of knowledge. It is also expected that the findings of this study would enlighten students, administrators and educationist of the importance of classroom management in secondary schools population.

\section{Methods:-}

The descriptive research survey design was adopted. This was considered appropriate for a comprehensive study of the class management and implications for effective delivery in the instructional process in secondary schools in Ekeremor Local Government Area, Bayelsa State of Nigeria.

The population of this study was made up of only teachers in government owned secondary schools in Ekeremor Local Government Area. From a population of 261 teachers in five government owned secondary schools in Ekeremor Local Government Area of Bayelsa State. 20 teachers were randomly sampled from each school. This gave a total number of one hundred (100) respondents which formed the sample size.

The research instrument used for this study was the questionnaire titled classroom management and effective instructional process questionnaire (CMEIPQ) developed by the researchers, which was subject to face and content validity. Also the reliability result of 74.2 was computed using Pearson correlational coefficient method.

It was administered to respondents in the selected secondary schools. The questionnaire was divided into two sections. Sections A and B. Section A was on the demographic data of respondents while Section B was made up of items in relation to the research questions. The respondents were required to tick strongly agree SA, Agree A, Disagree D, or Strongly Disagree (SD) as responses questions or items that were contained in the questionnaire.

The data were arranged according to bio-data and three research questions that guided the study.

Data Analysis:-

Analysis of the Bio-data of the respondents is shown in tables 1 and 2.

Table 1:- Frequency distribution of the Respondents by sex.

\begin{tabular}{|l|l|l|}
\hline Gender & Male & \% \\
\hline Male & 55 & $62.5 \%$ \\
\hline Female & 33 & $37.5 \%$ \\
\hline Total & $\mathbf{8 8}$ & $\mathbf{1 0 0 \%}$ \\
\hline
\end{tabular}

Source: Field Work (2019)

Table 1 shows the sex of respondents. The result revealed that 55 of the respondent are male, representing 62.5 percent of the entire respondents, while 33 respondents are female representing 37.5 percent of the respondents. The analysis therefore revealed that male respondents are in the majority.

Table 2:-Frequency Distribution of the Respondents by Age

\begin{tabular}{|l|l|l|}
\hline Age Range & Frequency & Percentage \\
\hline $20-28$ years & 9 & $10.2 \%$ \\
\hline $29-35$ years & 29 & $33 \%$ \\
\hline $36-45$ years & 32 & $36.4 \%$ \\
\hline 46 and above & 18 & $21 \%$ \\
\hline Total & $\mathbf{8 8}$ & $\mathbf{1 0 0 \%}$ \\
\hline
\end{tabular}

Source: Field Work (2019)

Table 2 above shows the age of the respondents. The data revealed that the respondents within the ages of $20-28$ years, 29 - 35 years, 36 - 45 years, 44 and above years are 9, 29, 32 and 18 respectively. They represent 10.2, 33, 
36.4 , and $20 \%$ respectively of the respondents. It shows therefore that majority of the respondents are within the age range of $36-45$ years.

Analysis to the research question are done in table 3 and 4

Table 3:-Analysis of causes of Poor Classroom Management

\begin{tabular}{|l|l|l|l|l|l|l|l|l|}
\hline S/N & Items SA & A & D & SD & Total & Mean & Design \\
\hline 1. & $\begin{array}{l}\text { Poor Seating and Sitting arrangement affect } \\
\text { Classroom management }\end{array}$ & 31 & 37 & 16 & 4 & 271 & 3.08 & Accepted \\
\hline 2 & $\begin{array}{l}\text { Teachers inability to handle discipline } \\
\text { problems faced in the classroom affect } \\
\text { classroom management }\end{array}$ & 35 & 41 & 12 & 0 & 287 & 3.03 & Accepted \\
\hline 3 & $\begin{array}{l}\text { Non-professionally trained teachers manage } \\
\text { classroom poorly. } 41\end{array}$ & 29 & 15 & 3 & 284 & 3.22 & Accepted \\
\hline 4 & $\begin{array}{l}\text { Lack of teachers preparation and professional } \\
\text { development in effective classroom } \\
\text { management }\end{array}$ & $\begin{array}{l}\text { Ineffective teaching affect classroom } \\
\text { management 27 }\end{array}$ & 42 & 17 & 2 & 270 & 3.06 & Accepted \\
\hline Grand Mean & & & & & & $\mathbf{3 . 1 5}$ & Accepted \\
\hline
\end{tabular}

Source: Field Work (2019)

Table 3 above showed that all the five items were accepted. This is because all the items 1,2,3,4 and 5 which has mean scores of 3.08, 3.02, 3.22, 3.38 and 3.06 respectively were above the criterion mean or 2.50. Consequently, the grand means was computed to be 3.15 which is above the criterion mean of 2.50 , thus accepted. This therefore indicates that these are causes of poor classroom management.

Table 4:-Analysis of the effect of Poor Classroom Management on the teaching and learning process.

\begin{tabular}{|l|l|l|l|l|l|l|l|l|}
\hline S/N & Items & SA & A & D & SD & Total & Mean & Design \\
\hline 6. & $\begin{array}{l}\text { Poor classroom management affects learning } \\
\text { negatively }\end{array}$ & 10 & 11 & 36 & 31 & 176 & 2.00 & Rejected \\
\hline 7 & $\begin{array}{l}\text { Lack of concentration by students on the } \\
\text { subjects taught affect their examination } \\
\text { performance }\end{array}$ & 25 & 40 & 19 & 4 & 262 & 2.97 & Accepted \\
\hline 8 & $\begin{array}{l}\text { Poor classroom management leads to non- } \\
\text { achievement of learning objectives }\end{array}$ & 29 & 42 & 17 & 1 & 277 & 3.14 & Accepted \\
\hline 9 & $\begin{array}{l}\text { Poor classroom management jeopardize the } \\
\text { quality of education }\end{array}$ & 35 & 39 & 14 & 0 & 285 & 3.38 & Accepted \\
\hline 10 & $\begin{array}{l}\text { Seating and sitting arrangement do not } \\
\text { enhance teaching and learning process }\end{array}$ & 7 & 22 & 41 & 18 & 194 & 2.20 & Rejected \\
\hline & Grand Mean & & & & & & $\mathbf{2 . 7 4}$ & Accepted \\
\hline
\end{tabular}

Source: Field Work (2019)

Table 4 above showed the items 6 , and 10 were rejected while item 7, 8 and 9 were accepted. This is because item 6 and 10 which have mean scores of 2.00 and 2.20 were below the criterion mean of 2.50 while item 7,8 and 9 which has mean scores of $2.94,3.14$ and 3.38 respectively were above the criterion mean of 2.50 , thus accepted. This therefore reveals that poor classroom management has effect on the instructional process.

Table 5:-Analysis of the implications of effective classroom management on effective delivering on the instructional process.

\begin{tabular}{|l|l|l|l|l|l|l|l|l|}
\hline S/N & Items & SA & A & D & SD & Total & Mean & Design \\
\hline 11 & $\begin{array}{l}\text { Effective classroom management enhance a } \\
\text { calm environment for effective teaching and } \\
\text { learning to take place }\end{array}$ & 38 & 13 & 0 & 288 & 3.27 & Accepted \\
\hline 12 & $\begin{array}{l}\text { Effective classroom management lead to } \\
\text { achievement of instructional objectives }\end{array}$ & 30 & 43 & 13 & 2 & 277 & 3.14 & Accepted \\
\hline
\end{tabular}




\begin{tabular}{|c|c|c|c|c|c|c|c|c|}
\hline 13 & $\begin{array}{l}\text { It leads to students participation in teaching } \\
\text { and learning process }\end{array}$ & 40 & 27 & 17 & 4 & 279 & 3.17 & Accepted \\
\hline 14 & $\begin{array}{l}\text { It enhance student interaction in the } \\
\text { classroom }\end{array}$ & 36 & 23 & 21 & 8 & 263 & 2.98 & Accepted \\
\hline 15 & $\begin{array}{l}\text { Effective classroom management has no } \\
\text { impact on the effectiveness in the } \\
\text { instructional process and learning }\end{array}$ & 8 & 28 & 30 & 22 & 198 & 2.25 & Rejected \\
\hline & Grand Mean & & & & & & 2.96 & Accepted \\
\hline
\end{tabular}

Source: Field Work (2019)

Table 5 revealed that item 11, 12, 13 and 14 were accepted, while item 15 was rejected. This is because item 11,12 , 13 and 14 which has mean scores of 3.27, 3.14, 3.17, and 2.98 respectively were above the criterion mean of 2.50, while item 15 which has mean score 2.25 was rejected because it was below the criterion mean of 2.50 . Consequently, the grand mean was computed to be 2.96 , thus accepted. This shows that there are implications of affective classroom management on effective teaching and learning process.

\section{Discussion of Findings}

After a careful analysis, the following findings were discovered. On research question one, on the causes of poor classroom management, it was discovered that poor seating and sitting arrangement affect classroom management, teachers inability to handle discipline, problems faced in the classroom affects classroom management, nonprofessionally trained teachers manages classroom poorly, lack of teacher preparation and professional development in classroom management affect effective classroom management, and ineffective teaching affect classroom management. This corroborated the findings of Arogundade and Bolarinwa (2011), their study revealed that poor teacher students' relationship, poor motivation, in adequate physical facilities and teachers work environment in terms of conducive environment has major constraints to effective classroom management.

Research question two on the effects of poor classroom management on the teaching and learning process, the results indicate that poor classroom management affects teaching and learning negatively, lack of concentration by students on the lesson taught has a result of poor classroom management affecting their examination performance, poor classroom management leads to non-achievement of learning objective, poor classroom management jeopardize the quality of education, and good seating and sitting arrangement enhance the instructional and learning process. Oskwe (2014), with a similar finding role that in a school system, where good classroom management is lacking, there is likely to be chaos which affects the teaching learning process and the standard of students' performance, hence a good teacher should be acquainted with such problems, be able to prevents and find solutions to such problem in order to promote quality secondary education.

On research question three, on implications of effective classroom management on effective teaching and learning process, it was discovered that effective classroom management enhance a calm environment for effective teaching and learning to take place. Effective classroom management leads to achievement of instructional objectives. It leads to students' participation and teaching and learning process. It enhance student teacher interaction in the classroom and that effective classroom management has impact on effective teaching and learning. This is in line with the findings of Marzano of Marzano (2003) that classroom management is a key to high student achievement. In their research they found out that teachers' actions in their classroom have twice the impact on student achievement as to school policies regarding curriculum, assessment, staff collegiality and community involvement. Effective classroom management provides effective instruction, so management is an integral part of learning process.

\section{Summary}

The broad purpose for embarking on this study was to investigate classroom management implications for effective instructional process in secondary school in Ekeremor Local Government Area of Bayelsa State.

It was discovered that classroom management has great implications for effective instructional process in the classroom. Effective classroom management was discovered to provide a calm learning objectives, students' participation in teaching and learning process, and enhance student-teacher interaction in the classroom while ineffective or poor classroom management affects the instructional process negatively. 
It leads to lack of concentration by students on the lesson taught which results to poor performance in examination, non-achievement of learning objectives and jeopardize the quality of education. Thus, poor or ineffective classroom management results from certain factors such as poor seating's and sitting arrangements, teacher inability to handle discipline problems faced in the classroom.

However, it was discovered that there are practices that enhance effective classroom management. Some of them are effective teaching, learners' effective participation in class and positive and negative reinforcement.

\section{Implications to Innovation in Education}

The traditional social structure of the classroom is one in which teachers dispense knowledge to students through classroom alternatives: like text books and possibly other media, such as other arrangement, privileges the teachers as controlling students learning and portrays the teacher and the textbook alone as bearing legitimate knowledge. However when a classroom becomes a learning community, the social structures transform into one in which teacher and learners work collaboratively to achieve important goals that may well have been established jointly. (Driscol 2000) inspector Merril, Merrienboer \& Driscoll, 2008).

The problem of classroom management is also affected by time, place and space ie seating and sitting arrangements. Hence some implications posed by this study is to overcome the problem of place, space and pace/time which in turn will put less strain on teachers on the issues of classroom management. This will enable learner to move at their place, convenience and pace. Naidu (2008) inspector et al outlined the following innovations in the instructional settings. They are as follows:

1. Group-based learning asynchronously - A mode of learning that enables individuals to learn in groups with online technologies in their own time at their own pace and from their own place.

2. Group-based learning synchronously - A mode of learning that enables individuals to learn in groups with online technologies at the same time and the same pace as that of the group but from their own place.

3. Self-paced learners offline - A mode of learning that enables individuals to study with portable technologies in their own time, at their own pace, and from their own place.

4. Self-paced learning online - A mode of learning that enables individuals to study online in their own time, at their own pace and from their own place.

Instruction facilitation is a particular feature of classroom instructions that has implications for how we develop instructional materials which is not.

\section{Conclusion:-}

Based on the findings of this study, the following conclusions were reached.

Effective classroom management provides a calm environment for effective instruction to take place. It leads to achievement of learning objectives, students' participation in the instructional process and enhances student-teacher interaction in the classroom which results to helping students and adjusting to school more easily, participate fully in the class activities and achieve better grades. Poor classroom management brings non-achievement of learning objective and jeopardizes the quality education. Poor seating and sitting arrangement, teachers' inability to handle and disciplined problems in the classroom, ineffective teaching and lack of teacher preparation and professional development are some of the causes of classroom management. It therefore shows that classroom management has great implications or impact on the instructional process in secondary schools in Ekeremor Local Government Area of Bayelsa State.

\section{Recommendations}

Based on the study, the following recommendations are made:

1. There is need to provide the right school climate in school where the teachers can practice classroom management skills without inhibition

2. There should be feedback on every aspects of teachers' evaluation. This will help to identify the area of strengths and weaknesses.

3. Teachers should be expose continually to different innovations in classroom management skills to improve instructional process. This could be through in-service training, conferences, seminars and workshops.

4. Students with consistent behavioral challenges should be referred to the school counselor for psychological support necessary to enhance the students' abilities. 
5. E-learning should be encouraged to overcome the problem of seating and sitting arrangement as a result of lack of space.

6. E-learning technologies both for offline and online studies should be made available for students to study at their time and pace.

7. ICT training should be provided to enable both students and teachers enjoys the benefit of offline and online computer mediated learning.

\section{References:-}

1. Alberto P \& Troutman A.C (1986). Applied Behaviour Analysis for Teachers in T K Henson \& B.F. Eller (1999:404) (Ed) Educational Psychology for Effective Teaching, Wadsworth Publishing Company, USA.

2. Arogundade, B. B \& Balarinwa, D. A (2011) Teachers work environment as correlate of classroom management in Ekiti State Government Secondary Schools. Journal of Emerging Trends in Educational Research and Policy Studies (JETERAPS) 2(4)234-238.

3. Brophy, J \& Good T. (2003) Looking in classrooms. New York Pearson Education, Inc

4. David, W.C (1996) understanding and managing student's problem behavior in schools: an integrative approach. Education Journal 24(2)15-28

5. Douyibo P.A (2016) Classroom Management Implications for Effective Teaching and Learning in Secondary Schools in Ekeremor Local Government Area of Bayelsa State. Unpublished project. Niger Delta University, Bayelsa State.

6. Duke D. L (1997). Editors preface in D.I Duke (Ed) Classroom Management $78^{\text {th }}$ year book of the National Society for the Study of Education part ii Chicago; University of Chicago Press.

7. Edwards, C. H (2004) Classroom discipline and management $4^{\text {th }}$ ed. New York: John Witey and sons.

8. Garret T. (2005) students and teacher centered classroom management: a case study of three teachers' beliefs and practices. Unpublished Doctoral Dissertation. The State University of New Jersey. New Bruns Wilt.

9. Gibbs, J.B. (2004) Attitudes and beliefs regarding classroom management between traditionally certified and alternatively certified high school teacher. Unpublished Doctoral Dissertation. The University of Southern Missi.ssl.pp, Haltiesburg.

10. Henson, K.T \& Eller, B.F (1999) Educational Psychology for effective teaching Wadsworth Publishing Company USA.

11. Hill, S \& Hill, T (1990). The collaborative classroom: A guide to cooperate learning south varre, Victoria Eleanor Curtain

12. Jones, V.F \& Jones, L.S (2012) comprehensive classroom management: Creating communities of support and solving problems $\left(10^{\text {th }}\right.$ Edition Prentice Hall)

13. Levin \& Nolan (1991) Principles of Classroom Management. A hierarchical approach. Engle Wood Diffs. N.J. Prenticethll

14. Martin N \& Baldwin B (1992) Beliefs regarding classroom management style: Difference between novice and experienced teachers. Paper presented at the annual meeting of the Southwest educational Research Association. San Antionio O, TX

15. Martin, N, Yin Z \& Baldwin, B (1997). Beliefs regarding classroom management style, Difference between make and female, Urban and rural secondary level teachers. Paper presented at the annual meeting of the American Educational Research Association, Chicago, IL

16. Marzano, R. J \& Marzano, J.S. (2003). The key management Educational Leadership, 61(i)

17. Sector, J.M, Merril, M. D, Merrienboer J.X \& Driscoli M.P (2008). Hand book of Research on Educational Communication and Technology. A Project of the Association of Educational Communities and Technology.

18. Venkat, L.K. (2010) Classroom Management in Integrated School set up. International Journal of Educational Science. 2(2) 95-10 and 19 kip publishers

19. Wisethrinthong K Scrisuthi C, Weangsmoot V. (2012). The Development of Classroom Management System for the Educational Extension Schools. European Journal of Social Science. 